\title{
Sochi 2001
}

\author{
By Ron Holloway
}

Spring 2001 Issue of KINEMA

\section{$11^{\text {th }}$ SOCHI OPEN RUSSIAN FILM FESTIVAL - "KINOTAUR" and $7^{\text {th }}$ SOCHI INTERNATIONAL FILM FESTIVAL - "KINOTAUR"}

If you happen to be among the uninitiated, then "Kinotaur" (read: "Cinema Taurus") on the calendar of world events stands for a film festival duet running parallel to each other in the subtropical Russian resort city of Sochi on the Black Sea. This year, the 11th Open Russian Film Festival (1-14 June 2000) was already running for a week when it linked with the 7th International Film Festival (7-17 June 2000). Back to back, they score as eminently attractive events on the festival calendar. Where else can film scholars easily make the acquaintance of fifty or more Russian filmmakers, among them some quite distinguished names who had contributed significantly to the Soviet art film of the past? Moreover, the retrospectives spotlighted St. Petersburg's Konstantin Lopushansky, Lenfilm's Vladimir Vengerov and Mikhail Schweizer, and Directors' Debuts at Gorky Film Studio. Add to this a quite decent International Competition, albeit restricted unfortunately to entries by directors who had made no more than three feature films, and you have the most picturesque, if not the best, film festival in Russia. One, too, that's on the rise to prominence -- for next year, according to an attending FIAPF festival referee, the international competition will be open to young filmmakers world-wide.

Organized by Mark Rudenstein, with movie idol Oleg Yankovsky at his side, Sochi benefits from the resourceful talents of program director Sergei Lavrentiev and critic Andrei Plakhov on his selection committee. Innovations also boost the festival's reputation abroad -- this year, for instance, open-air screenings were provided nightly for a non-paying public on the portico before the Winter Palace (the venue used for Russian entries), and the nightly events drew masses! Indeed, when Bakhtyar Khudojnazarov's Luna Papa, awarded the festival's Golden Rose, was shown, the audience spilled over the seating arena, causing passing taxi drivers to stop and watch from the roofs of their cars. Much of their attention was focussed on the antics of Russian actress Chulpan Khamatova and her desperate search for the "Tom Cruise" who stole her love and left her with child, and when the screening ended, a wave of applause and whistles erupted from a crowd of 3,000. Visibly moved by the spectacle, Irakli Kvirikadze, the gifted Georgian screenwriter of this spirited fairy tale set in a Tajikistan village, one of magic and mystery, voiced candid wonder: "That wasn't applause -- it was an explosion!"

Judging from the enthusiastic response of crowds inside and outside the Winter Palace, one cannot fault the commercial success of Russian cinema on home grounds. Alexei Uchitel's Dnevnik ego zheny (His Wife's Diary), awarded the follow-up Grand Prize, comes across as a convincing portrait of poet-writer Ivan Bunin (1870-1953), who received the Nobel Prize for Literature in 1933. Although stylistically the film bears the heavy imprint of the Russian art film, we do feel the joy and pain of the troubled Bunin (Andrei Smirnov) through the diary kept by his loving yet distressed wife (Galina Tyunina) during their exile in the south of France before, during, and after the Second World War -- ironically Bunin was to die (on a train to deliver a lecture in Italy) in the same year as Stalin, his lifelong nemesis.

Alexei Balabanov's Brat II (Brother II) picks up where the previous box-office hit Brother (1997) left off -- this time, the stakes are even higher: Danila Bagrov (played by Sergei Bodrov Jr.) travels to Chicago with his loony brother (Viktor Sukhorukov) to avenge the murder of a war buddy and take on more of the mafia than before. Roman Kachanov's amusing debut feature DMB (Demobbed), awarded the FIPRESCI Prize, depicts the escapades of a merry trio of army recruits as experienced by the screenwriter-directoractor himself. Georgy Danelia's Fortuna (Fortune), another funny, clever comedy in the hands of one of Russia's most popular directors, recalls -- at least in theme: life on a Volga river boat -- the Jean Vigo classic L'Atalante (France, 1934). And Alexander Proshkin's Russky bunt (The Captain's Daughter) was another open-air crowd-pleaser -- in addition, this action-packed historic epic about Pugachev's peasant revolt as penned by Pushkin also received a bundle of prizes on awards night.

As for the International Competition, Djordje Milosavlevi's Tockovi (Wheels, Yugoslavia) rightly deserved 
the Grand Prize awarded by the jury headed by India's Mrinal Sen. A black comedy by a talented writerplaywright-screenwriter making his debut as a film director, it takes the pulse of an isolated and boycotted Belgrade. When a young man is forced to stop during a rainstorm at a roadside inn called "Wheels," he finds himself confronted by a weird assortment of stranded motorists: conmen, black-market operators, petty thieves, mafia hitmen -- all suspecting the worst of the young stranger in their midst. As hard-hitting as it is comical, Wheels confirms once again that New Yugoslav Cinema is a movement to be reckoned with on the international scene.

Although Can Togay's Egy tel az isten hata magott (A Winter in the Back of Beyond, Hungary-France), awarded the Special Jury Prize, delights as a personal cinematic fairy tale, it strains belief as a village chronicle about unrequited love and the folly of youth. The setting is an isolated mountain village on the Hungarian border to Slovakia, where the only respite from boredom is the weekend movie -- note: this is 1989, and you would think television would have made some inroads. One day, the motorcyclist in charge of bringing the film print has an accident on the road -- worse: a snowstorm cuts the village off from the outside world for the entire winter. All is not lost, however, for the village innkeeper finds old prints in storage dating back to German Expressionism!

Another standout in the competition was Auli Mantila's Pelon maantiede (Geography of Fear, Finland), awarded the FIPRESCI Prize. The second feature by a visionary woman director, this combination psychothriller and detective story first confronts the viewer with varied psychological insights into the mental states of the protagonists, then rubs out the genre's usual narrative lines by image-distortion, jump-cuts, and multilayered camera techniques. Since a womanizer's murder might be traced to female victims with a known grudge, revenge surfaces as a motive -- much as it did in the Ridley Scott's Thelma and Louise.

To their credit, Sergei Lavrentiev and Andrei Plakhov scoured the festival circuit for promising young directors -- and came back with some remarkable finds. Sebastian Schipper's Absolute Giganten (Gigantic, Germany), a poignant tale of youths burning off steam on an all-night spree, was seen at the Berlinale. Min Byung-Chun's Yoo ryung (Phantom, the Submarine, South Korea), an action-thriller set inside a nuclear submarine with atomic warheads aimed by its crazed commander at key Japanese cities, was booked at Pusan. Alice Nellis's Ene bene (Eeny Meany, Czech Republic), a light comedy of manners set at a polling place at election time in a Czech town, was picked up at Pilsen. And James Marsh's Wisconsin Death Trip (USA-UK), an eery and unsettling chronicle of absurdities that happened in a small Midwest town at the end of the $19^{\text {th }}$ century, was discovered at Rotterdam.

Three retrospectives were highlighted in the international program. Not many foreign guests were familiar with the ten Soviet films in the "Musicals under the Red Banner" series, most of them produced in the 1960s. The quintet in the retro "South Korea: Unknown Film Empire" ran the artistic gamut from Bay YongKyun's awarded Dharmaga tongjoguro kan kkadalgun (Why Has Bodhi-Dharma Left for the East?, 1988) to Lee Myung-Se's highly entertaining cop-caper Injung sahjung bolgut up dah (Nowhere to Hide, 1999). And in the retrospective honouring Hungary's Peter Bacso you could see four of his once-banned or seldom-seen political features: Nyar a hegyen (Summer on the Hill, 1967), A tanu (The Witness, 1981), Tegnapelött (The Day Before Yesterday, 1982), and Te rongyos élet (Oh, Bloody Life, 1982).

Lastly, international jury member Yevgeny Tsymbal presented his controversial documentary titled Obikhovenny bolshevizm (Common Bolshevism), an indictment against both Lenin and his brand of Communism that still haunts Russia till the present day. Too compact and loaded with arguments to consume at one sitting, Common Bolshevism requires repeated viewing to weigh the facts as presented in this maelstrom of facts and information by the historian-filmmaker. Suffice it to say that due to access to previously restricted archive material, Lenin's personal portrait and his place in world history are undergoing heavy scrutiny.

\section{References}

\section{AWARDS}

\section{Open Russian Competition}


Golden Rose: Bakhtiar Khudoinazarov's Luna Papa

Grand Prize: Alexei Uchitel's Dnevnik ego zheny (His Wife's Diary)

Special Jury Prize: Alexander Proshkin's Russky bunt (The Captain's Daughter)

Best Actress: Svetlana Smirnova, Chetyrnadtsat tsvetov radougy (Fourteen Colors of the Rainbow), director Dmitry Svetozarov

Best Actor: Sergei Makovetsky, Russky bunt (The Captain's Daughter), director Alexander Proshkin

Best Musical Score: Mikhail Taryverdiev, Russky bunt (The Captain's Daughter), director Alexander Proshkin

\section{International Competition}

Grand Prize: Djordje Milosavlevi's Tockovi (Wheels, Yugoslavia)

Special Jury Prize: Can Togay's Egy tel az isten hata magott (A Winter in the Back of Beyond, HungaryFrance)

Best Actress (ex aequo): Tinna Gunnlaugsdottir, Ungfruin goda og husid (Honour of the House, IcelandDenmark-Sweden-Norway), director Gudny Halldorsdottir, and Iva Janžurová, Ene bene (Eeny Meany, Czech Republic), director Alice Nellis

Best Actor (collective award): Frank Giering, Florian Lukas, Antoine Monot, Absolute Giganten (Gigantic, Germany), director Sebastian Schipper

\section{Kinotavr Awards}

Kinotavr Film Festival Prize: Georgi Danelia's Fortuna (Fortune)

Kinotavr Debut Prizes:

- fiction: Elena Lanskaya's Mogla by y zhit (Might As Well Live)

- documentary: Andrei Murashov's Sokrat skazal (Socrates Said)

- animation: Ekaterina Sokolova's Nastupila osen (Autumn Has Come)

\section{FIPRESCI Awards}

International Competition: Auli Mantila's Pelon maantiede (Geography of Fear, Finland)

Russian Competition: Roman Kachanov's DMB (Demobbed)

\section{Author Information}

Ron HOLLOWAY (1933-2009) was an American critic, film historian, filmmaker and correspondent who adopted Europe as his home in the early fifties and spent much of his life in Berlin. He was an expert on the study of German cinema and against all odds produced, with his wife Dorothea, the journal German Film, keeping us up-to-date with the work of directors, producers and writers and the showing of German films around the world.

In 2007, Ron Holloway and his wife were awarded the Berlinale Camera Award. Ron also received the Bundesverdienstkreuz (German Cross of Merit), Polish Rings, Cannes Gold Medaille, the American Cinema Foundation Award, the Diploma for Support of Russian Cinema and an honorary award from the German Film Critics' Association.

Ron was also a valued contributor to Kinema for the past fifteen years. 